Article

\title{
When Does Expanded Eligibility Translate into Increased Take-Up? An Examination of Parental Leave Policy in Luxembourg
}

\author{
Merve Uzunalioglu ${ }^{1,2, *}$, Marie Valentova ${ }^{2}$, Margaret $\mathrm{O}^{\prime}$ Brien $^{1}$ and Anne-Sophie Genevois ${ }^{2}$ \\ 1 Thomas Coram Research Unit, Department of Social Sciences, UCL Institute of Education, University College London, \\ London, WC1H 0AA, UK; E-Mails: merve.uzunalioglu.17@ucl.ac.uk (M.U.), m.obrien@ucl.ac.uk (M.O.B.) \\ ${ }^{2}$ Living Conditions Department, Luxembourg Institute of Socio-Economic Research, L-4366 Esch-sur-Alzette, Luxembourg; \\ E-Mails: merve.uzunalioglu@liser.lu (M.U.), marie.valentova@liser.lu (M.V.), anne-sophie.genevois@liser.lu (A.-S.G.) \\ * Corresponding author
}

Submitted: 29 October 2020 | Accepted: 2 February 2021 | Published: 11 June 2021

\begin{abstract}
This article aims to explore the role of eligibility for parental leave as a determinant of access and as an enabler of leave take-up. To analyse the link between eligibility and take-up, we study a unique policy change in Luxembourg's parental leave scheme. The country's 2016 parental leave reform relaxed the eligibility criteria to enable marginal part-time working parents to access the parental leave scheme for the first time. We focus on this change and examine to what extent relaxing the eligibility criteria translated into increased take-up by the marginal part-time working parents who became eligible. To quantify this transition, we analyse trends in and patterns of eligibility for the scheme in Luxembourg between 2009 and 2018 among first-time parents working full-time, part-time, or marginal part-time hours. We use a subsample of Luxembourg-resident, cohabiting, first-time parents $(\mathrm{N}=6,254)$ drawn from the social security data. Our analysis shows that as eligibility is dependent on individual factors, it has similarities among mothers and fathers, whereas take-up is notably greater for mothers. After the reform, we observe that marginal part-time working mothers started taking parental leave, but up to 2018, the reform's outreach to marginal part-time working fathers remained limited. We also find that foreign national parents are less likely to be eligible for parental leave and have lower take-up rates. Despite the gendered parental leave take-up behaviours in parallel with international evidence, marginal part-time working mothers' positive response to the reform indicates progress towards strengthening women's labour market attachment in Luxembourg.
\end{abstract}

\section{Keywords}

eligibility; employment; leave take-up; Luxembourg; marginal part-time; parental leave

\section{Issue}

This article is part of the issue "The Inclusiveness of Social Rights: The Case of Parental Leave Policies" edited by Sonja Blum (University of Hagen, Germany) and Ivana Dobrotić (University of Oxford, UK / University of Zagreb, Croatia).

(C) 2021 by the authors; licensee Cogitatio (Lisbon, Portugal). This article is licensed under a Creative Commons Attribution 4.0 International License (CC BY).

\section{Introduction}

Eligibility criteria determine the extent of a policy's potential beneficiaries. Restricting the access to welfare benefits by using eligibility criteria is common practice and respective non-take-up is well-studied in social policies (van Oorschot, 1991). Contrarily, research on the eligibility for work-life reconciliation policies, particularly access to parental leave, has been somewhat limited.
More recently, some investigation of eligibility has begun to emerge in parental leave research (see, for example, Dobrotić \& Blum, 2020; EIGE, 2020; Twamley \& Schober, 2019). Yet what determines eligibility in the first place, and once it has been attained, the extent to which it translates into take-up remain under-researched. To add to well-established parental leave take-up literature, we return to the foundations of parental leave take-up by analysing the determinants of eligibility in a 
single-country setting. The eligibility criteria vary across countries and this variation affects the size of the eligible population, which is the denominator of the takeup calculations. Therefore, we focus on one country and this specification prevents us from overlooking disparities in take-up rates. Furthermore, when the change in eligibility criteria addresses a specific group of parents, their behaviours affect overall take-up rates in the country. The expansion in parental leave eligible population would increase the denominator for the take-up calculations, yet if newly-eligible parents do not take parental leave, then overall parental leave take-up rates for that country drops. Therefore, for an outside observer, it may not be entirely clear whether this decrease is due to a general population behaviour or it is due to the newlyeligible parents' parental leave take-up behaviour. With the 2016 parental leave reform, Luxembourg provides us with an excellent opportunity to study this.

In our understanding, parental leave eligibility conveys a real opportunity for parents to have (or to not have) access to leave. The opportunity for decisionmaking regarding whether to take parental leave contributes to an advantage. This advantage can be conceived as the capability to perform employee and parenting roles reciprocally (Javornik \& Yerkes, 2020). By providing such leverage, the policy acts as an institutional means to offer an enabling environment for parents, children, and workplaces. This enabling environment allows parents to hold roles as employees and responsibilities as parents, children to have the opportunity to receive parental care, and workplaces to retain talent and avoid productivity losses. Paving the way toward equal access to parental leave would translate into an equal opportunity for young children to experience the benefits of parental-leave-rich households (O'Brien, 2009).

In the work-life reconciliation policies domain, parental leave policies differ from other childcare policies by explicitly addressing parents and protecting their employment throughout a leave period. By equally targeting mothers and fathers, such policies operate as a care and a gender equality measure (Koslowski, Blum, Dobrotić, Kaufman, \& Moss, 2020). However, uneven access to parental leave seeds inequalities between parents who are eligible for leave and those who fail to meet the eligibility criteria (O'Brien, Aldrich, Connolly, Cook, \& Speight, 2017). While this does not mean that all eligible people can afford to take parental leave, or prefer to do so, those who are not eligible lack the choice. Therefore, it is crucial to understand if any parent is left behind due to policy design. Additionally, it also becomes necessary to discover how the targeted group responds when a policy relaxes the eligibility criteria and focuses on a larger population. Whether the policy change can establish or transform behaviour remains an interesting question.

To this end, our aim in this article is to use social security records to assess the extent to which the expansion in eligibility criteria in Luxembourg's parental leave reform could turn newly-eligible-i.e., those who work between 10 and 20 hours per week and are classified as marginal part-time workers-first-time parents into leave-takers. Our objective is to examine the evolution of eligibility and take-up over time, particularly for newly-eligible parents and across different parent groups. We first provide a descriptive picture of annual eligibility and take-up rates, and then discuss the main determinants of eligibility among first-time parents in Luxembourg. We display the characteristics of parents who are excluded from parental leave due to eligibility criteria and explore the factors affecting the probability of being eligible across full-time, part-time, and marginal part-time working parents. We then focus on marginal part-time working parents-who only became eligible for the leave after the reform-and examine the interplay between eligibility changes and the take-up behaviour among mothers and fathers. Before the analysis, we discuss parental leave eligibility and determinants of take-up based on existing evidence and summarize Luxembourg's leave system. We finish with discussion and conclusion sections.

\section{Determinants of Eligibility and Take-Up of Parental Leave}

Access to leave and its benefits (e.g., compensation), which are not necessarily mutually exclusive, are bound by policy designs that require parents to meet eligibility criteria. These criteria are likely to be based on factors such as length of residence, employment history, duration of contract, or household composition; framing parental leave as a right related to citizenship or employment (Dobrotić \& Blum, 2020; EIGE, 2020; Koslowski et al., 2020). The degree of accessibility and policy designs vary among European countries (Koslowski et al., 2020). A recent comparative study documents that across the EU-28, $29 \%$ of women and $20 \%$ of men are ineligible for parental leave due to unemployment or inactivity, employment conditions, self-employment, or personal and household characteristics (EIGE, 2020).

Existing literature has documented associations between eligibility requirements and growing inequalities among parents (O'Brien et al., 2017; Twamley \& Schober, 2019). Particularly when leave is defined as an employment right with eligibility rules, inequalities appear not only among those who are outside the labour force but also among the working population (Campbell, 2006; Ghysels \& Van Lancker, 2011). The disparities in access based on employment conditions require attention to be paid to countries' labour force composition, the type of jobs available in the market, and any activation measures. This is particularly important for a country such as Luxembourg, where parental leave (as a paid entitlement) is contingent on employment and the labour force consists of a large share of foreign nationals.

In parallel, relevant literature also shows that when policies relax the eligibility criteria for a scheme and 
expand its potential reach, specific targeted groups are likely to increase their take-up (Margolis, Hou, Haan, \& Holm, 2019). When eligibility criteria are linked to traditional employment modalities, they become more prone to exclude parents working under non-standard contracts (Margolis et al., 2019; O'Brien, 2009; Patnaik, 2019). This may generate accessibility clusters and could turn parental leave into the property of only specific groups of parents, thereby excluding those in insecure or atypical employment (Dobrotić \& Blum, 2020; Ghysels \& Van Lancker, 2011).

Being eligible for parental leave establishes the basis for potential take-up. However, the decision of whether to take parental leave involves a more complex combination of factors. While the policy design is likely to establish norms and behaviours (Hobson, 2018; Kangas \& Rostgaard, 2007), individual preferences, workplace characteristics, managerial and collegial attitudes and partners' characteristics are factors that have been documented as determinants of parental leave take-up. Relevant literature shows that the majority of people who take parental leave are mothers, but when the policy defines leave as an individual entitlement and specifies quotas on a 'use-it-or-lose-it' basis, it encourages fathers' take-up (Bergqvist \& Saxonberg, 2017; O’Brien \& Wall, 2017).

Research shows that parents with a higher level of education, higher income, and with more gender-equal attitudes toward sharing care responsibilities are more likely to be leave takers (Duvander \& Johansson, 2012; Kaufman \& Bernhardt, 2015; Twamley \& Schober, 2019). This is also particularly apparent among men who have a higher-educated and high earning partner (Bygren \& Duvander, 2006; Geisler \& Kreyenfeld, 2011). The compensation level and potential income loss appear to be essential concerns of parents when deciding about taking parental leave (O'Brien, 2009; O'Brien, Brandth, \& Kvande, 2007; Valentova, 2011). Further, research shows low take-up among disadvantaged fathers due to financial difficulties (Pragg \& Knoester, 2017). The disadvantages and respective lower take-up might also be more prevalent among people with an immigrant background (Ma, Andersson, Duvander, \& Evertsson, 2019). This may be related to the economic opportunities for foreignborn parents in their country of residence, and how long they have lived there. Regarding the latter, adapting to new norms might also take a long time.

In addition, some studies stress the crucial role of workplaces and how managerial and collegial attitudes and the composition of the workforce influence parents' leave take-up behaviour (Allard, Haas, \& Hwang, 2011; Haas \& Hwang, 2019). When fathers work in male-dominated workplaces, or mothers work in femaledominated workplaces, fathers are less likely to take-up parental leave (Bygren \& Duvander, 2006). Working in the private sector is also associated with lower leave take-up for fathers (Bygren \& Duvander, 2006; Lappegård, 2012).

\section{The Case of Luxembourg}

\subsection{Labour Market}

Located in continental Europe and having borders with Belgium, France, and Germany, Luxembourg is a country with 626,000 inhabitants, of whom $48 \%$ are foreign nationals (Le Gouvernement de Grand-Duche de Luxembourg, 2020a). Consequently, Luxembourg's labour force is highly multinational, and of the Luxembourg-resident population, about half of the labour force is non-native (STATEC, 2020).

Luxembourg has a long history of a corporatist welfare regime and traces of being a conservative society, with men holding the primary breadwinner role and women principally taking on caregiving responsibilities (Hartmann-Hirsch, 2010; Zhelyazkova \& Ritschard, 2018). With the legacy of this traditionally gendered division of labour and low female employment, particularly after parenthood (Zhelyazkova \& Ritschard, 2018), Luxembourg has enacted various policies to support families with young children and to address women's employment. Alongside, the employment rate for women with a youngest child aged 2 or under has increased over time, from $45.6 \%$ in 1998 to $71.6 \%$ in 2014 (OECD, 2018).

As is the case in many other European countries, most part-time employment is undertaken by women in Luxembourg. While the proportion of men in the labour force working part-time is consistently around the $2 \%$ level, 30\% of women between the age of 25 and 54 work part-time in the country (Eurostat, 2020). Further, between 2009 and 2018, men between the ages of 25 and 54 and who work on average less than 20 hours per week correspond to less than $1 \%$ of Luxembourg's labour force (OECD, 2020). Of the same age group during the same observation window, women who work less than 20 hours per week comprise $6.1 \%$ of the labour force (OECD, 2020). The 2016 parental leave reform particularly associates with a notable proportion of women in part-time employment-including marginal part-time work-and a political agenda aiming to improve gender equality in the country.

\subsection{Parental Leave}

In 1999, following an EU Commission Directive, the Luxembourg government introduced a parental leave scheme. Before this, family-related leave policies had been limited to 20 weeks paid maternity leave and 10 days special leave for fathers, to be taken at the time of the childbirth or adoption. By providing job protection and remuneration, parental leave brought a promise of change in the division of labour within the household and in the labour market. Luxembourg's introduction of this policy can be considered a progressive step in its transformation to a more gender-equal society (Valentova, 011).

Since 1999, parental leave in Luxembourg was 6 months duration (12 months in the case of part-time 
take-up) for each parent for each new-born, and had three main features: a paid, individual, and nontransferable right. The scheme was available equally to all employed (i.e., self-employed as well as salaried) parents who had been contributing to the social security system for the 12 months before taking parental leave. Hence, with leave being reserved for all working parents but granted only after meeting the eligibility criteria, Luxembourg's parental leave policy can be categorized as a selective adult-worker model (Dobrotić \& Blum, 2020) and described as an employment-related social investment mobilized by the state.

On 1 December 2016, the new parental leave reform (hereafter just termed reform) became effective in Luxembourg. Before this, parents who worked less than 20 hours per week did not have access to parental leave. With the reform, the eligibility criteria for weekly working hours were relaxed, with access expanded to include parents working for as little as 10 hours per week. This meant that parents working between 10 and 20 hours weekly (i.e., marginal part-time working parents) became eligible for parental leave. Parents working fewer than 10 hours per week remain ineligible. The criterion of continuous contribution to social security remained for the newly eligible marginal part-time workers.

There are other components of the reform that incentivize individuals, once eligible, to take parental leave: Parents have more flexibility regarding the mode of leave (full-time, part-time, or divided up, e.g., 1 day per week off over 20 months, or any 4 months over 20 months) and enhanced remuneration (increased from a monthly flat-rate payment (approximately $€ 1,800$ ) to a dynamic calculation of salary and the number of hours worked (between $€ 2,100$ and $€ 3,500$ per month). Additionally, with the reform, parents can take the period of leave up to the time their child turns six, whereas before this was only until the child turned five. It is also important to note that the reform date does not act as a cut-off point. Parents who had their child or children in the pre-reform period and who comply with the eligibility criteria can still benefit from the new policy.

We propose that with the increased flexibility, higher compensation, and expansion in the scope of potential beneficiaries, the reform could attract more people to take parental leave. We also acknowledge that because the reform brings changes to the policy's different elements concurrently, it is challenging to identify which factor or factors affect parents' leave take-up behaviour. However, because marginal part-time working parents had no access to parental leave before the reform, their post-reform leave take-up can be associated with it. While these parents were already loosely connected to the labour market and are likely to have more flexible arrangements in work-life reconciliation, having access to parental leave provides them with an assurance to stay in the labour market.

In this context, we first look how eligibility rates evolved over time among full-time, part-time, and marginal part-time working parents, and then focus on marginal part-time working parents' leave take-up after the reform.

\section{Data and Sample}

Our analysis is based on social security data, known as the IGSS data set, provided by the Luxembourg government's General Inspectorate of Social Security. It is an administrative dataset containing monthly sociodemographic, social security, and employment records for each parent registered in the Luxembourg social security system.

Our sample, extracted from the IGSS data set, covers Luxembourg-resident, cohabiting, first-time parents of 6,254 children born between December 2009 and June 2017. This sample includes 331 mothers $(5.29 \%$ of mothers in the full sample) and 223 fathers (3.57\% of fathers) who worked marginal part-time jobs in the pre-birth period. Our choice to investigate first-time parents with an only child was driven by data limitations, as we are unable to link parental leave and children for the pre-2016 period. Hence, in the case of a parent with more than one child, we cannot identify which period of leave was taken for which child.

We have an observation period of 18 months after the childbirth, ending in December 2018; two years after the reform was enacted. At the time of writing this article, this was the most recent data available on parental leave in Luxembourg. Our selected pre-reform period goes back to 2009, enabling us to present a trend over the last decade. We also restrict our sample to parents who reside in Luxembourg. Although cross-border workers account for $46 \%$ of the Luxembourg labour force (Le Gouvernement de Grand-Duche de Luxembourg, 2020b) and are eligible for parental leave, we decided to exclude them from our analyses due to information asymmetry (i.e., key variables on partners of crossborder workers are missing). In addition, we exclude self-employed parents. In the IGSS dataset, the number of hours worked (an essential variable for calculating parental leave eligibility and take-up) is reported by the employer. Moreover, self-employed people represent only a small proportion in our sample, which does not suffice to analyse them as a distinct group. Our specific interest group comprises marginal part-time working parents who are employed in the private sector. Hence, excluding self-employed parents is appropriate for the scope of this article.

Table 1 presents the descriptive statistics, already profiling ineligibility for parental leave in Luxembourg. It is apparent that about $28 \%$ of mothers and $14 \%$ of fathers were not working 4-5 months before the birth of their child. As these parents do not meet the continuous social security contribution and employment criteria, they are not eligible for the parental leave scheme. Most of the parents who were not working are from other EU-28 countries (not the neighbouring countries or 
Table 1. Descriptive statistics.

\begin{tabular}{|c|c|c|c|c|}
\hline & \multicolumn{2}{|c|}{ Mother } & \multicolumn{2}{|c|}{ Father } \\
\hline & Mean & SD & Mean & SD \\
\hline Age & 30.5 & 5.30 & 32.8 & 6.00 \\
\hline \multicolumn{5}{|l|}{ Nationality } \\
\hline Luxembourger & .37 & .484 & .388 & .487 \\
\hline German & .025 & .157 & .022 & .148 \\
\hline Belgian & .023 & .150 & .032 & .177 \\
\hline French & .082 & .274 & .091 & .288 \\
\hline Portuguese & .20 & .400 & .218 & .413 \\
\hline Other EU-28 & .15 & .358 & .14 & .348 \\
\hline Other & .14 & .346 & .104 & .306 \\
\hline \multicolumn{5}{|c|}{ Number of working hours } \\
\hline Not working & .2812 & .449 & .147 & .354 \\
\hline Marginal part-time & .0529 & .223 & .035 & .185 \\
\hline Part-time & .069 & .254 & .041 & .199 \\
\hline Full-time & .596 & .490 & .775 & .417 \\
\hline \multicolumn{5}{|l|}{ Sector } \\
\hline Not working & .302 & .459 & .141 & .348 \\
\hline Private & .614 & .486 & .739 & .438 \\
\hline Public & .083 & .276 & .118 & .324 \\
\hline $\mathrm{N}$ & \multicolumn{2}{|c|}{6,254} & \multicolumn{2}{|c|}{6,254} \\
\hline
\end{tabular}

Source: IGSS (2020). Authors' calculation.

Portugal) and non-European backgrounds. This finding is in line with Luxembourg's national statistics. We also know that the unemployment rate among foreign-born individuals is higher than the overall unemployment rate in Luxembourg. As of 2019, while the overall unemployment rate in Luxembourg was 5.4\% (World Bank, 2020) the foreign-born unemployment rate was $6.7 \%$ (OECD, 2020).

Of the mothers who were not working, 34\% are non-European, $25 \%$ are from other EU-28, and $14 \%$ are Portuguese. Similarly, of the fathers who were not working, 25\% are non-European, $30 \%$ are from other EU-28, and $13 \%$ are Portuguese. Having to omit a large fraction of the parents at the initial stage can be taken as an indication of the variations in access to parental leave because of discrepancies in labour market behaviour among different groups of parents.

The descriptive statistics show that on average, fathers are slightly older than mothers ( 33 years of age vs 30). Our sample demographically mirrors Luxembourg's national statistics, with a large proportion of foreign nationals parents residing in the country. The majority of non-native Luxembourger parents are from Portugal (around 20\%), followed by other EU-28-meaning not from neighbouring countries or Portugal; generally, from Italy (15\%)-and non-Europeans (14\%). Nearly $60 \%$ of mothers and $78 \%$ of fathers work full-time, and not working is more prevalent among mothers $(28 \%)$ than fathers (14\%). The majority are employed in the private sector. However, a considerable proportion of them $(30 \%$ of mothers and $14 \%$ of fathers) did not report sector information, because they were not working at the time of data collection.

Because marginal part-time working parents are the parental leave reform's specific concern, we present their characteristics below in Table 2. This subsample shows different characteristics than the overall sample. The subsample is more homogenous compared to full sample. They are younger, mostly employed in the private sector, and they come from non-Luxembourg backgrounds. Most of this group (both for mothers and fathers) are either from Portugal, other EU-28, or non-European countries.

\section{Results}

\subsection{Eligibility for Parental Leave in Luxembourg}

Eligibility for parental leave in Luxembourg is defined by parents' pre-leave employment characteristics, including social security contributions and the number of hours worked per week. Below, we detail the trends in eligibility rates for parental leave in Luxembourg for mothers and fathers according to their weekly working hours. To calculate eligibility rates, we follow Nelson and Nieuwenhuis (2019) proposed methodology. We divide the number of eligible people by the reference population (i.e., first-time parents whose children were born between December 2009 and June 2017) for each year in the observation period separately for fathers and mothers.

Because the expansion in eligibility specifically focuses on marginal part-time working parents, we present 
Table 2. Descriptive statistics for marginal part-time working parents.

\begin{tabular}{|c|c|c|c|c|}
\hline & \multicolumn{2}{|c|}{ Mother } & \multicolumn{2}{|c|}{ Father } \\
\hline & Mean & SD & Mean & SD \\
\hline Age & 29.6 & 5.608 & 30.8 & 6.51 \\
\hline \multicolumn{5}{|l|}{ Nationality } \\
\hline Luxembourger & .187 & .390 & .183 & .388 \\
\hline German & .009 & .094 & .004 & .066 \\
\hline Belgian & .018 & .133 & .035 & .186 \\
\hline French & .051 & .221 & .062 & .243 \\
\hline Portuguese & .477 & .500 & .372 & .484 \\
\hline Other EU-28 & .129 & .336 & .165 & .372 \\
\hline Other & .126 & .500 & .174 & .380 \\
\hline \multicolumn{5}{|l|}{ Sector } \\
\hline Not working & .16 & .367 & .094 & .292 \\
\hline Private & .839 & .367 & .906 & .292 \\
\hline Public & $\cdot$ & $\cdot$ & $\cdot$ & $\cdot$ \\
\hline $\mathrm{N}$ & \multicolumn{2}{|c|}{331} & \multicolumn{2}{|c|}{223} \\
\hline
\end{tabular}

Source: IGSS (2020). Authors' calculation.

parents' eligibility rates in separate clusters according to their number of working hours (see Figure 1). It is important to note that the variable for the number of working hours represents the average number of hours worked per week 4-5 months before the childbirth. The eligibility variable shows if the parent became eligible at any point during the observation period. While the small sample size of marginal part-time working parents may be concerning, it is important to note that this is based on social security records for the population of interest. It summarizes the evolution of ineligibility rates over the

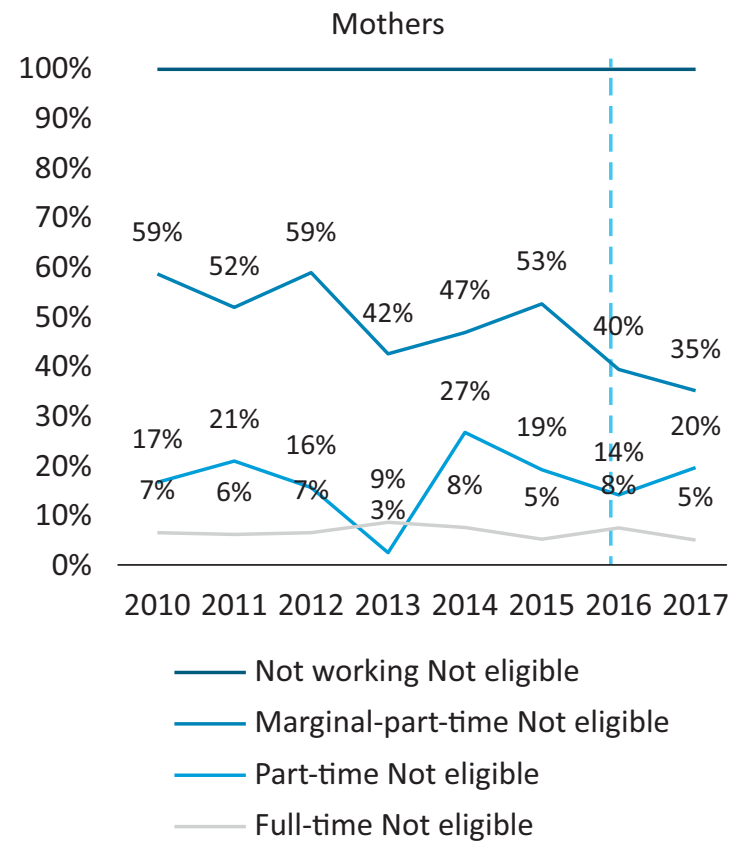

last decade, showing a gradual improvement in access to parental leave in Luxembourg. The biggest change is observed among those working marginal part-time hours. This confirms the expansion with the reform. However, the question remains of which group of parents have been affected by the change in eligibility. To tackle this, we used probit regressions for mothers and fathers across different employment categories.

Because of the policy's nature, we use variables concerning parents' employment characteristics (e.g., full-time, part-time, or marginal part-time employment;

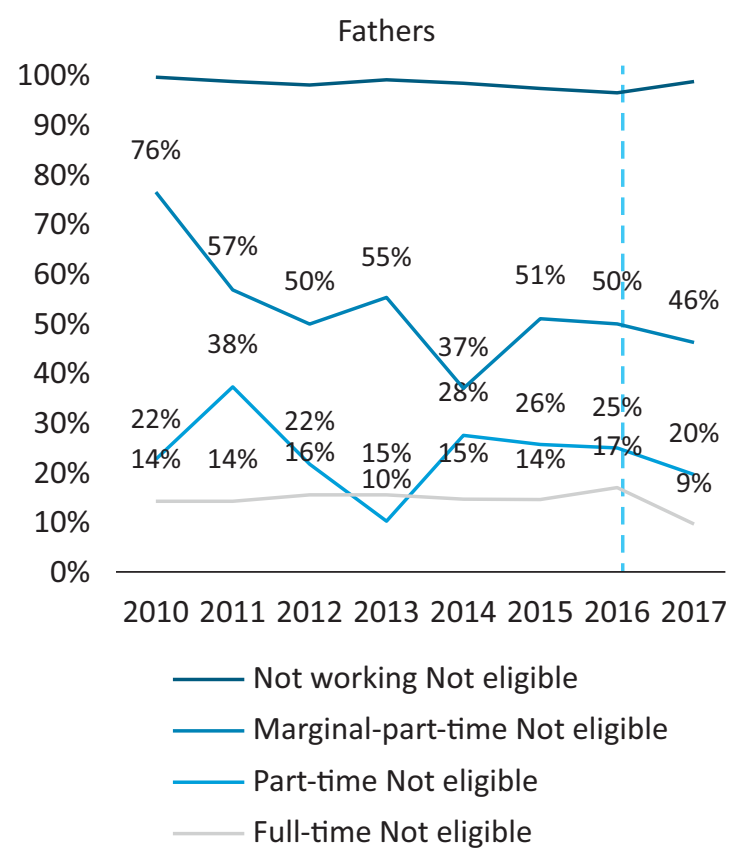

Figure 1. Trends in eligibility for parental leave in Luxembourg, 2009-2018. Source: IGSS (2020). Authors' calculation. Notes: Not working mothers $=1712$, MPT mothers $=324$, PT mothers $=422$, FT mothers $=3611$. Not working fathers $=897$, MPT fathers $=217$, PT mothers $=258$, FT fathers $=4701$. 
private sector, public sector, or not working) in addition to their individual characteristics such as age and nationality as explanatory variables. We also add variables indicating the characteristics of the partner, including age, nationality, and sector. Because of data limitations, we lack potentially important information such as education level or any attitudinal variables. However, thanks to the data's precision and representativeness, we can still provide an accurate picture for Luxembourg. Additionally, including the partners' characteristics is important in the country context. In Luxembourg, each eligible parent is granted parental leave that can be used until the child turns six. However, one of the periods of leave has to be taken immediately after the maternity leave, or the other partner loses the opportunity to take parental leave (Valentova, 2011). Hence a person's access to parental leave and the use of it is likely to influence their partner's behaviour. With these variables, we define our outcome variable as eligibility for parental leave during the 18 months after the childbirth. This is a binary variable, with 0 representing ineligibility and 1 representing eligibility.

An analysis of the factors that influence parents' eligibility status by their full-time, part-time, or marginal part-time working status indicates that eligibility is driven by individual characteristics. It is only when partnered with a man who is not working that mothers' probability of being eligible for parental leave is significantly lower than those who are partnered with a man working in the private sector. This suggests potential assortative mating (Esping-Andersen, 2007) in Luxembourg, where partner relationships tend to comprise either those who are eligible or those who are ineligible.

It is important to note that this clustering already displays limited within-group variations, particularly for variables related to the employment sector. Some $83 \%$ of marginal part-time working mothers and $91 \%$ of part-time working mothers are in the private sector. Consequently, we do not see these variables in their regression models (see Table 3 ). For the individual characteristics, we observe nationality as an important determinant of eligibility. For full-time working mothers, being from France, Portugal, other EU-28, or non-European countries are associated with lower probabilities of eligibility for parental leave compared with Luxembourgnative full-time working mothers. While we do not observe any significant differences based on nationalities among part-time working mothers, marginal

Table 3. Parental leave eligibility for mothers according to number of working hours.

\begin{tabular}{|c|c|c|c|c|c|c|}
\hline & \multicolumn{2}{|c|}{$\begin{array}{c}\text { Full-time } \\
\text { working mothers }\end{array}$} & \multicolumn{2}{|c|}{$\begin{array}{c}\text { Part-time } \\
\text { working mothers }\end{array}$} & \multicolumn{2}{|c|}{$\begin{array}{l}\text { Marginal part-time } \\
\text { working mothers }\end{array}$} \\
\hline & Coeff. & z & Coeff. & z & Coeff. & z \\
\hline Age & $.002 *$ & 2.36 & .003 & 0.77 & $.018 * *$ & 2.91 \\
\hline \multicolumn{7}{|l|}{ Nationality } \\
\hline German & -.028 & -1.19 & -.051 & -0.34 & . & \\
\hline Belgian & -.017 & -0.76 & -.131 & -0.69 & .055 & 0.27 \\
\hline French & $-.036^{*}$ & -2.35 & .071 & 1.14 & .020 & 0.15 \\
\hline Portuguese & $-.052 * * *$ & -3.35 & -.051 & .059 & -.040 & -0.42 \\
\hline Other EU-28 & $-.053 * *$ & -3.12 & -.105 & .090 & $-.206^{*}$ & -1.96 \\
\hline Other & $-.103^{* * *}$ & -4.14 & -.092 & .082 & .196 & -1.93 \\
\hline Log of monthly hours of work & .014 & 0.24 & .120 & .097 & $.179 * * *$ & 4.61 \\
\hline \multicolumn{7}{|l|}{ Sector } \\
\hline Public & .017 & 1.30 & & & & \\
\hline Partner's age & .001 & 1.55 & .005 & 1.34 & -.001 & -0.18 \\
\hline \multicolumn{7}{|l|}{ Partner's nationality } \\
\hline German & -.057 & -1.64 & .063 & 0.50 & .099 & 0.42 \\
\hline Belgian & -.010 & -0.47 & .008 & 0.07 & -.122 & -0.63 \\
\hline French & $-.035^{*}$ & -1.97 & .029 & 0.28 & -.159 & -1.17 \\
\hline Portuguese & .0001 & 0.01 & .019 & 0.33 & -.027 & -0.32 \\
\hline Other EU-28 & -.008 & -0.60 & -.117 & -1.20 & -.200 & -1.81 \\
\hline Other & -.040 & -2.14 & -.126 & -1.33 & -.090 & -0.75 \\
\hline \multicolumn{7}{|l|}{ Partner's sector } \\
\hline Public & -.006 & -0.46 & .069 & 1.16 & .202 & 1.56 \\
\hline Not working & $-.044 * *$ & -2.87 & $-.270 * *$ & -2.87 & $-.173^{*}$ & -2.00 \\
\hline Reform & $.021 * *$ & 2.62 & .024 & 0.51 & .135 & 1.86 \\
\hline $\mathrm{N}$ & \multicolumn{2}{|c|}{3667} & \multicolumn{2}{|c|}{434} & \multicolumn{2}{|c|}{328} \\
\hline
\end{tabular}

Source: IGSS (2020). Authors' calculation. Note: Average marginal effects. 
part-time non-European working mothers appear 20 percentage points less likely to be eligible for parental leave. This is consistent with the descriptive picture, where we noted a high proportion of non-European parents in ineligible groups.

We include the log of the monthly number of working hours in our models. For the marginal part-time working mothers, an increase in their monthly working hours appears to increase their probability of being eligible. Mothers in this group are likely to have an irregular working schedule, hence an increase in their number of working hours may increase their attachment to the labour market and this may be reflected in their eligibility status.

When we look at the factors that influence fathers' eligibility for parental leave in Luxembourg (see Table 4), we observe some similarities with the mothers. However, this resemblance disappears among marginal part-time working fathers, which is likely to be related to the very small sample size. For marginal part-time working fathers, it is only an increase in the number of working hours in a month that boosts their probability of being eligible for parental leave. For full-time working fathers, being a non-native Luxembourger reduces their probability of eligibility for parental leave, as seen in the case of mothers. Those who work in the public sector have a 4 percentage points higher likelihood of being eligible than private-sector workers. If they had their children in the post-reform period, their probability of being eligible also rises. However, if their partner is not working (i.e., not eligible for parental leave) their likelihood also diminishes compared with other fathers whose partners are working full-time.

\subsection{Take-Up of Parental Leave in Luxembourg: The Case of Marginal part-time Working Parents}

Marginal part-time working parents are the focus of the eligibility expansion of parental leave reform in Luxembourg. One of our goals in this article is to analyze the extent of which, after this expansion, marginal part-time working parents started taking parental leave. As before, we take the 18 months after the childbirth as our observation period. Since parents who are not eligible for parental leave are not of interest regarding leave take-up (i.e., their take-up status would always be zero), we limit our base sample to parental-leave-eligible parents. Consequently, the sample size is reduced to 142 marginal part-time working mothers and 56 marginal

Table 4. Parental leave eligibility for fathers according to the number of working hours.

\begin{tabular}{|c|c|c|c|c|c|c|}
\hline & \multicolumn{2}{|c|}{$\begin{array}{c}\text { Full-time } \\
\text { working fathers }\end{array}$} & \multicolumn{2}{|c|}{$\begin{array}{c}\text { Part-time } \\
\text { working fathers }\end{array}$} & \multicolumn{2}{|c|}{$\begin{array}{l}\text { Marginal part-time } \\
\text { working fathers }\end{array}$} \\
\hline & Coeff. & z & Coeff. & z & Coeff. & z \\
\hline Fathers' age & $.003 * *$ & 2.86 & .011 & 1.76 & .005 & 0.76 \\
\hline \multicolumn{7}{|l|}{ Nationality } \\
\hline German & $-.114^{*}$ & -2.51 & & & & \\
\hline Belgian & $-.071^{*}$ & -2.09 & .053 & 0.30 & .109 & 0.48 \\
\hline French & $-.077^{* *}$ & -3.45 & -.101 & -0.82 & .163 & 1.01 \\
\hline Portuguese & $-.052 * *$ & -2.97 & .096 & 1.07 & .106 & 0.87 \\
\hline Other EU-28 & $-.105^{* * *}$ & -4.51 & .006 & 0.05 & .151 & 1.13 \\
\hline Other & $-.137 * * *$ & -5.39 & -.044 & -0.41 & -.102 & -0.95 \\
\hline Log of monthly working hours & $.233^{* *}$ & 2.63 & .226 & 1.45 & $.211 * * *$ & 4.21 \\
\hline \multicolumn{7}{|l|}{ Sector } \\
\hline Public & $.043^{* *}$ & 2.79 & & & & \\
\hline Partner's age & $.005^{* * *}$ & 3.90 & .004 & 0.64 & .005 & 0.71 \\
\hline \multicolumn{7}{|l|}{ Partner's nationality } \\
\hline German & -.046 & -1.19 & & & .244 & 1.36 \\
\hline Belgian & .038 & 1.23 & -.037 & -0.15 & -.207 & -0.88 \\
\hline French & -.041 & -1.71 & -.035 & -0.31 & .035 & 0.24 \\
\hline Portuguese & .018 & 1.06 & -.033 & -0.34 & -.116 & -0.92 \\
\hline Other EU-28 & -.024 & -1.15 & .061 & 0.65 & -.071 & -0.53 \\
\hline Other & .002 & .018 & -.124 & -1.02 & -0.37 & .117 \\
\hline \multicolumn{7}{|l|}{ Partner's sector } \\
\hline Public & -.011 & -0.57 & -.061 & -0.46 & .165 & 0.74 \\
\hline Not working & $-.044 * *$ & -3.43 & .016 & 0.26 & -.022 & -0.33 \\
\hline Reform & $.046 * * *$ & 3.73 & .052 & 0.79 & .113 & 1.28 \\
\hline $\mathrm{N}$ & \multicolumn{2}{|c|}{4823} & \multicolumn{2}{|c|}{253} & \multicolumn{2}{|c|}{222} \\
\hline
\end{tabular}

Source: IGSS (2020). Authors' calculation. Note: Average marginal effects. 
part-time working fathers. To calculate take-up rates, using the eligible population base, we divide the number of leave-takers by the number of eligible parents in the same period.

Figure 2 shows an interesting picture regarding marginal part-time working parents' leave take-up behaviour. One immediately visible detail is that mothers and fathers in this group follow a different trajectory. It may be confusing at first to see how, before the reform, there were marginal part-time working parents who were leave-takers. This relates to the nature of the data. While the number of hours worked per week represents a point 4-5 months before the childbirth, the leave take-up variable shows parents' eligibility status during the 18 months subsequently. Hence, some of the parents working marginal part-time hours before the childbirth might have increased their working hours in the post-birth period and thus have qualified for the leave when they applied. Figure 2 also illustrates a notable increase in the leave take-up of marginal part-time working mothers who had their first child after 2015. This also coincides with the implementation of the reform. It is likely that some of the mothers who had their child in 2015 became eligible with the reform and then took parental leave.

We then employ a probit regression (see Table 5), as we did earlier, using leave take-up during the 18 months after the childbirth as the binary outcome variable. We find that an increase in the monthly number of working hours significantly increases the probability of marginal part-time working mothers' leave take-up. This may indicate that mothers who are closer to regular part-time work might have stronger attachment to the labour market, or alternatively, that those who worked as little as 10 hours per week might not have had the urge or need to take any leave. It might have been easier for them to keep their existing work schedules rather than disrupting them by taking parental leave. Moreover, they might have held positions where they could have easily been replaced; hence taking parental leave could have jeopardized their career prospects. Although parental leave comes with job protection, there might be issues between employers and workers demanding to take parental leave. Being from Portugal, compared with native Luxembourgers, decreases the likelihood of taking parental leave by 33 percentage points. For the fathers in the same group, we do not observe an inclination to take parental leave. This is also likely to be related to the very small sample size. Of the 56 marginal part-time working fathers who were eligible to take parental leave, only six did so. This confirms the evidence from literature indicating a low rate of leave uptake by disadvantaged fathers and those not engaged in full-time stable employment (Geisler \& Kreyenfeld, 2018). The gender differences also support the evidence of mothers shouldering the caregiving and leave-taking roles.

\section{Discussion}

Relaxing the eligibility criteria for parental leave comes with the presumption that the eligible population increases by the magnitude of those who become entitled to take parental leave. It can also be expected that number of parental-leave-takers will also increase accordingly. However, the reflection of this increase in the eligible population as the number of parental-leavetakers is likely to be smaller. The evidence from relevant literature extensively documents a gap between number of eligible parents and actual parental-leave-takers, and our analysis showed that Luxembourg also conforms this pattern. Luxembourg's parental leave reform relaxes eligibility criteria for a specific group, and this allows us to test the extent to which parents used their new entitlement to become parental-leave-takers, and for the newly-eligible parents the factors play a role driving their parental leave take-up behaviours.

The expansion of parental leave in Luxembourg only targets those who work on a marginal part-time basis, which comprises about $5 \%$ of the mothers and $3 \%$ of the fathers in our dataset. The specificity of the target

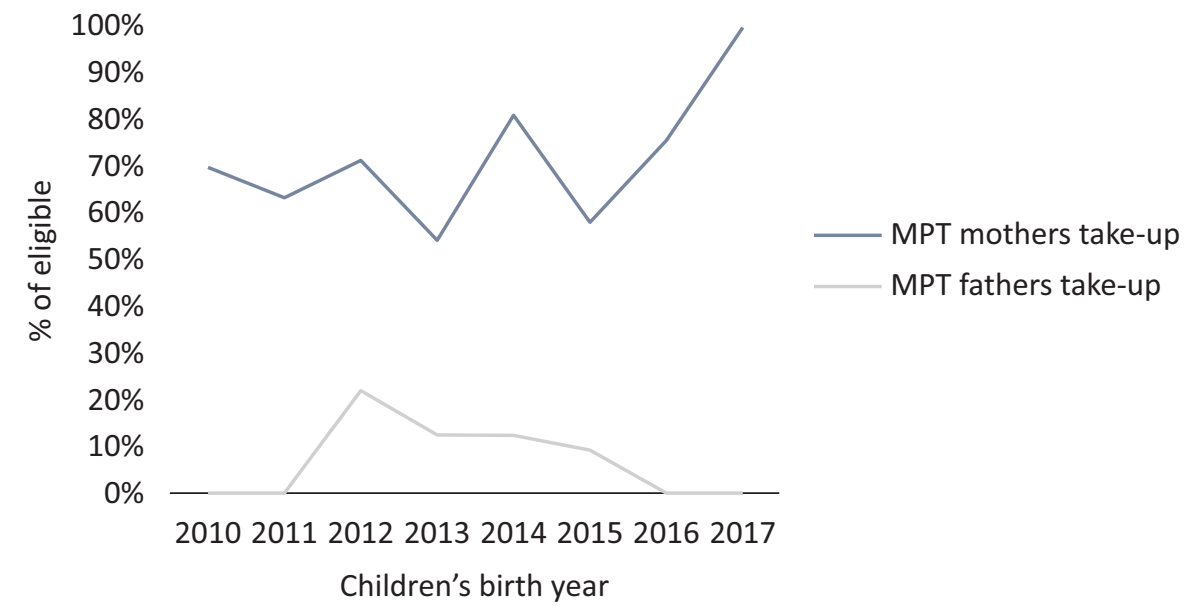

Figure 2. Leave take-up by marginal part-time workers, Luxembourg-resident first-time parents. 
Table 5. Determinants of marginal part-time working mothers' leave take-up in the post-reform period.

\begin{tabular}{|c|c|c|}
\hline \multirow[t]{2}{*}{ Leave take-up } & \multicolumn{2}{|c|}{ Marginal part-time working mothers } \\
\hline & Coeff. & $\mathrm{z}$ \\
\hline Age & .004 & 0.48 \\
\hline \multicolumn{3}{|l|}{ Nationality } \\
\hline Belgian & -.116 & -0.50 \\
\hline French & -.056 & -0.59 \\
\hline Portuguese & $-.333 * *$ & -3.05 \\
\hline Other EU-28 & -.223 & -1.57 \\
\hline Other & -.222 & -1.47 \\
\hline Log of monthly working hours & $.211^{* * *}$ & 3.59 \\
\hline Fathers' age & .000 & 0.03 \\
\hline \multicolumn{3}{|l|}{$\begin{array}{l}\text { Fathers' nationality } \\
\text { German }\end{array}$} \\
\hline Belgian & -.327 & -1.29 \\
\hline French & -.002 & -0.02 \\
\hline Portuguese & .110 & 1.06 \\
\hline Other EU-28 & .113 & 0.58 \\
\hline Other & -.229 & -1.24 \\
\hline \multicolumn{3}{|l|}{ Fathers' sector } \\
\hline Public & .003 & 0.02 \\
\hline \multicolumn{3}{|l|}{ Not working } \\
\hline $\mathrm{N}$ & & \\
\hline
\end{tabular}

Source: IGSS (2020). Authors' calculation. Note: Average marginal effects.

group and the small size may raise questions about the aim of this component in the reform, particularly for men. Alternatively, the more extensive involvement of women can be taken as a component of the country's progressive efforts toward strengthening women's labour market attachment over the last decade. By securing their jobs and providing compensation, parental leave operates to prevent parents' detachment from the labour market during the first years of parenthood. Hence, even though descriptively-due to our focused sample (i.e., Luxembourg-resident first-time parents) and the small proportion of marginal part-time working parents within the sample-we are able to show an increasing trend for leave take-up in this group of women.

Another concern might relate to the nature of marginal part-time employment and the characteristics of the parents in this group. It could be assumed that parents who work for few weekly hours already have more 'free time' for childcare or are less constrained by long hours of work. It could also be argued that leaving the labour market has fewer income penalties for marginal part-time working parents than for those working full-time hours. Given that their income would be lower than full-time workers and that most marginal parttime working mothers live with full-time working men, income loss in those households is likely to be lower than in others where mothers have stronger labour market attachment and higher salaried incomes. However, irre- spective of the extent of the loss, the reform offers an opportunity to protect jobs and thus income. These parents' inclusion in the parental leave scheme conveys an explicit message that their labour is valued.

While it is promising to see that the reform established an inclination for its use among marginal parttime working mothers who became eligible for parental leave for the first time, it is worth discussing the type of parents who remained excluded from the leave scheme in Luxembourg. Our analysis reveals that many parents failed to meet the conditions, therefore remaining ineligible. These people are primarily foreign nationals, the majority either from non-European countries, or other EU-28, specifically Portugal (which makes up most of the foreign national population in Luxembourg). We also show that of those who are among the working population, these parents, i.e., non-native Luxembourgers, had significantly lower probabilities of eligibility for parental leave than Luxembourg natives. Foreign national parents' inadequate access to parental leave is widely seen in other country contexts (see, for example, Ellingsæter, Kitterød, \& Østbakken, 2019; Tervola, Duvander, \& Mussino, 2017). However, with half of its population being foreign nationals, non-native Luxembourgers' limited access to parental leave raises questions concerning the capacity of the policy to reach all parents in such a multinational society. It may indicate that foreign national parents are more likely to have a scarcity of resources 
or lack an established community (Yerkes, Hoogenboom, \& Javornik, 2020) to enable them to be in the labour market and provide care for their children concurrently. The arguable inclusivity of the parental leave policy in Luxembourg resonates with Sainsbury's examination of the Swedish case, "expansion of services does not necessarily benefit vulnerable groups" (Sainsbury, 2018, p. 223).

\section{Conclusion}

In this article, we examined the trends and determinants of parental leave eligibility and take-up in Luxembourg, and the extent to which an expansion in eligibility was followed by increased take-up. We concluded that the increase in take-up was small compared to enlargement in parental-leave-eligible sample. The take-up behaviours of the newly-eligible parents were gendered, and also the low take-up trend among non-native Luxembourgers persisted.

To explore eligibility and take-up, and their links in the case of marginal part-time working parents in Luxembourg, we used social security records. We looked at the trends and patterns of parental leave eligibility by groups of parents working full-time, part-time, and marginal part-time hours. The data revealed that there was a steady increase in mothers' and fathers' eligibility during the observation period, with a larger increase in the post-reform period. In line with the higher labour force participation of fathers, they tend to have more access to parental leave than mothers.

Did expanded eligibility translate into increased take-up? Our analysis showed that the probability of a parent's eligibility is defined by their individual characteristics, and age, number of working hours, and nationality seem to be important determinants. Our findings showed that once eligible, marginal part-time working mothers did indeed start opting into the parental leave program. In parallel with the existing international evidence, mothers composed the majority of leave-takers among marginal part-time working parents. However, eligibility expansion did not appear to be a strong enough factor for change in the case of marginal part-time working fathers, albeit our sample size for fathers was smaller than for mothers. The small sample size may also be taken as a sign of mothers being more flexible and adapting their shorter working hours more than fathers.

The increase in eligibility and its reflection in the takeup rate among marginal part-time working mothers in the post-reform period can be taken as a positive development toward strengthening female labour force participation in Luxembourg. Although the targeted group of parents was arguably only loosely connected to the labour market, the reform appeared to have been a successful initiative in terms of securing their position in the market and preventing them from dropping out.

Future observations over a longer time frame are needed to track and understand the intersection between foreign national parents' employment behaviour, parents in irregular employment, and the effects of extending parental leave eligibility to those parents, particularly fathers. Similar to other countries (see, e.g., Bygren \& Duvander, 2006; Sainsbury, 2018), Luxembourg reproduced the long-standing cultural and structural legacy of higher parental leave-taking by mothers and lower levels by fathers. In fact, it is not entirely surprising to observe that only six of the 56 marginal part-time working fathers who were eligible for parental leave in 2018 took it. This pattern convinced us to conclude, similarly to Heckman and Smith (2004), that eligibility is a necessary but never a sufficient condition for parental leave take-up.

This article was the first attempt to analyse the expanded eligibility of the relatively recent parental leave reform in Luxembourg. In view of the country's highly multinational labour force and innovative approach to parental leave, the reform requires further investigation once the data allows us to follow a full eligibility period for parents of all backgrounds.

\section{Acknowledgments}

This project is supported by the Fonds National de la Recherche, Luxembourg (the Luxembourg National Research Fund [FNR]), no. 12540500. The authors are grateful for the insightful comments received by the editors and the reviewers. The authors are also thankful for the informative feedback they received from Dr Katherine Twamley, Dr Petra Sauer, Dr Sait Bayrakdar, and $\mathrm{Dr}$ Luise Görges in earlier versions of the article. Finally, the authors would like to acknowledge Prof Sara Connolly and Dr Matthew Aldrich for being the inspiration to apply this work to Luxembourg.

\section{Conflict of Interests}

The authors declare no conflict of interests.

\section{References}

Allard, K., Haas, L., \& Hwang, C. P. (2011). Familysupportive organizational culture and fathers' experiences of work-family conflict in Sweden. Gender Work and Organization, 18(2), 141-157. https://doi. org/10.1111/j.1468-0432.2010.00540.x

Bergqvist, C., \& Saxonberg, S. (2017). The state as a normbuilder? The take-up of parental leave in Norway and Sweden. Social Policy and Administration, 51, 1470-1487. https://doi.org/10.1111/spol.12251

Bygren, M., \& Duvander, A. Z. (2006). Parents' workplace situation and fathers' parental leave use. Journal of Marriage and Family, 68, 363-372. https://doi.org/ 10.1111/j.1741-3737.2006.00258.x9

Campbell, A. J. (2006). Proceeding with "care": Lessons to be learned from the Canadian parental leave and Quebec daycare initiatives in developing a nation- 
al childcare policy. Canadian Journal of Family Law, 22(2), 171-222.

Dobrotić, I., \& Blum, S. (2020). Inclusiveness of parental leave benefits in twenty-one European countries: Measuring social and gender inequalities in leave eligibility. Social Politics, 27(3), 588-614.

Duvander, A. Z., \& Johansson, M. (2012). What are the effects of reforms promoting fathers' parental leave use? Journal of European Social Policy, 22, 319-330. https://doi.org/10.1177/0958928712440201

EIGE. (2020). Eligibility for parental leave in EU Member States. European Institute for Gender Equality. Retrieved from https://eige.europa.eu/publications/ eligibility-parental-leave-eu-member-states

Ellingsæter, A. L., Kitterød, R. H., \& Østbakken, K. M. (2019). Immigrants and the 'caring father': Inequality in access to and utilisation of parental leave in Norway. Ethnicities, 20(5), 959-982. https://doi.org/ $10.1177 / 1468796819890109$

Esping-Andersen, G. (2007). Sociological explanations of changing income distributions. American Behavioural Scientist, 50(5), 639-658. https://doi. org/10.1177/0002764206295011

Eurostat. (2020). Part-time employment as percentage of the total employment, by sex and age (\%). Eurostat. Retrieved from https://appsso.eurostat.ec.europa. eu/nui/show.do?dataset=Ifsa_eppga\&lang=en

Geisler, E., \& Kreyenfeld, M. (2011). Against all odds: Fathers' use of parental leave in Germany. Journal of European Social Policy, 21(1), 88-99. https://doi.org/ $10.1177 / 0958928710385732$

Geisler, E., \& Kreyenfeld, M. (2018). Policy reform and fathers' use of parental leave in Germany: The role of education and workplace characteristics. Journal of European Social Policy, 29(2). https://doi.org/ $10.1177 \% 2 F 0958928718765638$

Ghysels, J., \& Van Lancker, W. (2011). The unequal benefits of activation: An analysis of the social distribution of family policy among families with young children. Journal of European Social Policy, 21(5), 472-485. https://doi.org/10.1177/0958928711418853

Haas, L., \& Hwang, C. P. (2019). Workplace support and European fathers' use of state policies promoting shared childcare. Community, Work \& Family, 22(1). https://doi.org/10.1080/13668803.2018.1556204

Hartmann-Hirsch, C. (2010). The state of the Luxembourg's welfare state: The effects of the crisis on a corporatist model shifting to a universalistic model (LISER Working Paper Series 2010-44). Esch-surAlzette: LISER.

Heckman, J., \& Smith, J. A. (2004). The determinants of participation in a social program: Evidence from a prototypical job training program. Journal of Labour Economics, 22(2), 243-298. https://doi.org/10.1086/ 381250

Hobson, B. (2018). Gendered dimensions and capabilities: Opportunities, dilemmas and challenges. Critical Sociology, 44(6), 883-898. https://doi.org/10.1177/
0896920516683232

IGSS. (2020). Luxembourg microdata platform on labour and social protection. IGSS. https://igss. gouvernement.lu/fr/microdata-platform/ comment.html

Javornik, J., \& Yerkes, M. A. (2020). Conceptualizing national family policies: A capabilities approach. In R. Nieuwenhuis \& W. Van Lancker (Eds.), The Palgrave handbook of family policy (pp. 141-167). Cham: Springer International Publishing.

Kangas, O., \& Rostgaard, T. (2007). Preferences or institutions? Work-family life opportunities in seven European countries. Journal of European Social Policy, 17(3), 240-256. https://doi.org/ 10.1177/0958928707078367

Kaufman, G., \& Bernhardt, E. (2015). Gender, work and childbearing: Couple analysis of work adjustments after the transition to parenthood. Community, Work \& Family, 18(1), 1-18. https://doi.org/ 10.1080/13668803.2014.928610

Koslowski, A., Blum, S., Dobrotić, I., Kaufman, G., \& Moss, P. (2020). International review of leave policies and related research 2020. International Network on Leave Policies \& Research. Retrieved from https://www.leavenetwork.org/annual-reviewreports/review-2020

Lappegård, T. (2012). Couples' parental leave practices: The role of the workplace situation. Journal of Family and Economic Issues, 33(3), 298-305. https://doi. org/10.1007/s10834-012-9291-6

Le Gouvernement du Grand-Duche de Luxembourg. (2020a, April 2). A small, but open society. Official Portal of the Grand Duchy of Luxembourg. Retrieved from https://luxembourg.public.lu/en/society-andculture/population/demographics.html

Le Gouvernement du Grand-Duche de Luxembourg. (2020b, June 1). Cross-border workers attached to Luxembourg. Official Portal of the Grand Duchy of Luxembourg. Retrieved from https://luxembourg.public.lu/en/work-and-study/ employment-in-luxembourg/frontaliers-attachesluxembourg.html

Ma, L. I., Andersson, G., Duvander, A. Z., \& Evertsson, M. (2019). Fathers' uptake of parental leave: Forerunners and laggards in Sweden, 1993-2010. Journal of Social Policy, 49(2), 361-381. https://doi.org/ 10.1017/S0047279419000230

Margolis, R., Hou, F., Haan, M., \& Holm, A. (2019). Use of parental benefits by family income in Canada: Two policy changes. Journal of Marriage and Family, 81(2), 450-467. https://doi.org/10.1111/jomf. 12542

Nelson, K., \& Nieuwenhuis, R. (2019). Analysing benefit coverage: A new analytical framework (Deliverable 9.1). Leuven: InGRID-Inclusive Growth. Retrieved from https://zenodo.org/record/3578183\#.YC_ cGrNpHIV

O’Brien, M. (2009). Fathers, parental leave policies, and 
infant quality of life: International perspectives and policy impact. Annals of the American Academy of Political and Social Science, 624, 190-213. https:// doi.org/10.1177/0002716209334349

O’Brien, M., Aldrich, M., Connolly, S., Cook, R., \& Speight, S. (2017). Inequalities in access to paid maternity and paternity leave and flexible work. London: NatCen Social Research. Retrieved from https://www.modernfatherhood.org/wp-content/ uploads/2017/11/Inequalities-Parental-LeaveReport-21st-Nov-2017-full-report-FINAL.pdf

O’Brien, M., Brandth, B., \& Kvande, E. (2007). Fathers, work and family life. Community, Work \& Family, 10(4), 375-386. https://doi.org/10.1080/136688 00701574971

O’Brien, M., \& Wall, K. (Eds.). (2017). Comparative perspectives on work-life balance and gender equality. Cham: Springer International Publishing.

OECD. (2018). Maternal employment. OECD. Retrieved from http://www.oecd.org/els/family/ database.htm

OECD. (2020). Foreign-born unemployment (indicator). OECD. Retrieved from https://data.oecd.org/ migration/foreign-born-unemployment.htm

Patnaik, A. (2019). Reserving time for daddy: The consequences of fathers' quotas. Journal of Labour Economics, 37(4), 1009-1059. https://doi.org/10.1086/ 703115

Pragg, B., \& Knoester, C. (2017). Parental leave use among disadvantaged fathers. Journal of Family Issues, 38, 1157-1185. https://doi.org/10.1177/ $0192513 \times 15623585$

Sainsbury, D. (2018). Policy constructions, immigrants' social rights and gender: The case of Swedish childcare policies. Journal of European Social Policy, 29(2), 213-227. https://doi.org/10.1177/ 0958928718762311
STATEC. (2020). Domestic payroll employment by citizenship and country of residence. STATEC. Retrieved from https://statistiques.public.lu/stat/ TableViewer/tableViewHTML.aspx?sCS_ChosenLang =en\&Reportld=12916

Tervola, J., Duvander, A.-Z., \& Mussino, E. (2017). Promoting parental leave for immigrant fathers-What role does policy play? Social Politics: International Studies in Gender, State \& Society, 24(3), 269-297. https://doi.org/10.1093/sp/jxx006

Twamley, K., \& Schober, P. I. A. (2019). Shared parental leave: Exploring variations in attitudes, eligibility, knowledge and take-up intentions of expectant mothers in London. Journal of Social Policy, 48(2), 387-407. https://doi.org/10.1017/ S0047279418000557

Valentova, M. (2011). Anticipated parental leave take up in Luxembourg. Social Policy and Society, 10(2), 123-138. https://doi.org/10.1017/ s1474746410000485

van Oorschot, W. (1991). Non-take-up of social security benefits in Europe. Journal of European Social Policy, 1(1), 15-30. https://doi.org/10.1177/0958 92879100100103

World Bank. (2020). Unemployment, total (\% of labour force) (modelled ILO estimate) [Data set]. Retrieved from https://data.worldbank.org/indicator/SL.UEM. TOTL.ZS?locations=LU

Yerkes, M. A., Hoogenboom, M., \& Javornik, J. (2020). Where's the community in community, work and family? A community-based capabilities approach. Community, Work \& Family, 23(5), 1-18. https://doi. org/10.1080/13668803.2020.1818547

Zhelyazkova, N., \& Ritschard, G. (2018). Parental leave take-up of fathers in Luxembourg. Population Research and Policy Review, 37. https://doi.org/ 10.1007/s11113-018-9470-8

\section{About the Authors}

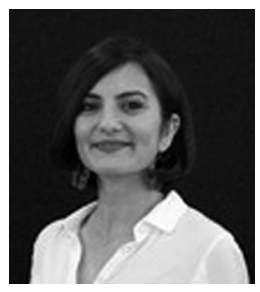

Merve Uzunalioglu is a PhD candidate in Social Sciences at the Thomas Coram Research Unit, Social Research Institute at the University College London (UCL) and Luxembourg Institute of Socioeconomic Research (LISER). In her doctoral research, she studies the impact of Luxembourg's parental leave reform within the scope of expanded access, evaluation of take-up and parents' behaviours across different workplaces. She is a junior affiliate to the International Network on Leave Policies \& Research and an AFR Individual PhD grant owner, funded by FNR. https://orcid.org/0000-0002-5814-0861

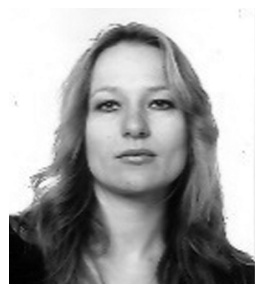

Marie Valentova (PhD) is a Senior Research Fellow at LISER specializing in quantitative sociology with a research portfolio in topics related to policy analysis, evaluation, family-work reconciliation, migration and social cohesion. She is a country representative for Luxembourg in the International Network on Leave Policies \& Research. Her research has been extensively published in peer-reviewed journals. Outside of academia, she collaborates with the Luxembourg Ministry of Family, Integration and the Greater Region and institutions like European Institute for Gender Equality. https://orcid.org/ 0000-0003-2190-9179; http://www.scopus.com/inward/authorDetails.url?authorID=16644209600\& partnerID=MN8TOARS 


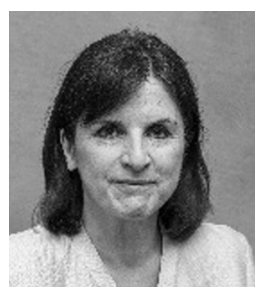

Margaret O'Brien (Professor) is the Director of the Thomas Coram Research Unit at UCL's Social Research Institute, where she is Professor of Child and Family Policy. Her research is in the field of fathers, work and family life, including COVID-19 impacts funded by the Economic and Social Research Council (ESRC) and the European Institute of Gender Equality (EIGE). She has published widely on gender equality, paternity and parental leave, and is a co-coordinator of the International Network on Leave Policies \& Research. https://orcid.org/0000-0002-9306-6871; https://www.scopus.com/ authid/detail.uri?authorld=23398116700

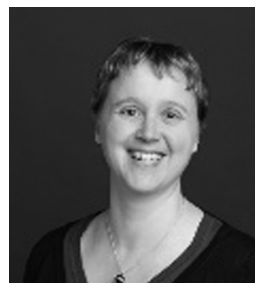

Anne-Sophie Genevois is a Data Analyst at LISER. She has more than 18 years of experience working with complex data sets, surveys and simulations. She is one of the key experts in Luxembourg's social security register data provided by the Ministry of Social Security. Her recent projects focus on tax-benefit microsimulation modellings and evaluation of parental leave policies. She is also a team member of the EUROMOD simulation model in Luxembourg since 2015. 